\title{
Cross-Regional Development of Enterprises and its Influencing Factors: An Empirical Study From Firm Heterogeneity \\ PANG Chen ${ }^{1,2}$
}

\author{
${ }^{1}$ School of Economics, Zhejiang University, Hangzhou, Zhejiang, 310027, China \\ ${ }^{2}$ School of Fashion, Zhejiang University, Hangzhou, Zhejiang, 310018, China \\ pangchen827@163.com
}

\begin{abstract}
Keywords: Cross-Regional; Spatial dispersion; Location decision-making; Firm heterogeneity Abstract. Based on the empirical literature, this paper introduced firm heterogeneity into classical location decision-making model. 1001 Chinese public manufacturing firms and their subsidiaries were used as samples to analyze their spatial cross-regional strategies and driving factors by conditional logistic regression. Results present that firm heterogeneity can influence the decisions of firms' spatial dispersion, larger enterprises with more knowledge workers are more likely to implement spatial-dispersion strategy. Different from production units, R\&D units are inclined to be located in cites with higher factor costs and closer to the parent company. Finally, conclusion and implications of these findings were also discussed and we also provide suggestions helpful for introducing superior enterprises and solving the unbalanced development of regional economy
\end{abstract}

\section{Introduction}

Recently rapid changes of consumers' demands and rising factor costs make increasing enterprises realize that it is difficult to produce diversified goods in one place. Companies, developing for many years, are inclined to break constraint of geographical boundary to take more geographical advantage of different areas. They have been changing the way they produce their products, veering from spatial integration (single location) to spatial dispersion along industrial chains to achieve economies of scale. In China, a prevailing phenomenon nowadays is that more enterprises with market power and technological advantage transfer their subsidiaries with knowledgeable activities (such as R\&D subsidiary, design department, etc) from their birthplaces to other cities. When this cross-regional spatial behavior has gradually become a trend, it will profoundly influence the reallocation of factor(labor, knowledge and so on) and regional economic strategy across different areas.

Previous studies focused on multinational enterprises, little effort has been made on this issue with different areas within a country. In China, vast territory and regional disparity in economy determined the variety and complexity in the way for enterprises to move to other areas. Thus, this study mainly focused on the characteristics and determinants of enterprises' cross-regional location decision, extended traditional location choice model, and took market capacity, geographical distance, labor cost, land price and degree of industry concentration as the basic study variables. In addition, our study introduced firm heterogeneity (firm size, technological level and research spending)into traditional location choice model, tested the proposed model in the cross-regional location choice context via conditional logistic regression method.

\section{Literature Review and Extended Model}

Firm heterogeneity and location choice.As traditional location theory, enterprises' spatial behavior has been related to their needs to achieve economies of scale and profit maximization[1]. Cross-regional development can give rise to transportation costs as well as some risks such as potential knowledge spillovers[2]. One of the most convenient assumptions in most previous researches is that all firms are identical which is least realistic. Recently substantial researchers have begun to realize firms' location choice behavior will vary enormously according to firms' characteristics such as size[3], productivity, technological level and workers heterogeneity[4-5]. Actually, as the micro 
decision-makers, firms always consider both benefits and cross-regional cost. Deep investigation should be conducted to explore micro-heterogeneity across firms and how heterogeneity affect location choice of firms[6].

Expected profit and extend model. A firm will consider expected profits in each of the prospective locations[7]. Some researchers have developed expected profit estimation according to New Economic Geography model of monopolistic competition[8], see Eq. 1.

$$
\ln \pi_{\mathrm{r}}=\alpha_{0}+\alpha_{1} \ln M A_{\mathrm{r}}+\alpha_{2} \ln \mathrm{w}_{\mathrm{r}}+\alpha_{3} \ln \mathrm{P}_{\mathrm{r}}+\alpha_{4} \ln \mathrm{z}_{\mathrm{r}}+\varepsilon \text {. }
$$

where $\pi_{\mathrm{r}}$ is firm's expected profit can be earned in each potential location $\mathrm{r}$. MA $\mathrm{A}_{\mathrm{r}}$ is "market access" of region $r$ and $w_{r}$ is the wage. $P_{r}$ is the intermediate input-price index in region $r$, and $z_{r}$ is the price of other factors (including land cost, transaction costs and so on).

From Eq. 1, market access generally can be estimated of two components: market capacity and transportation cost. Spatial proximity will reduce transportation cost, thus it can be measured by geographical distance. Intermediate input-price index mainly evaluate supplier access with firm's location choice. Because of market incompleteness of intermediate product, it is difficult to be measured directly. Industrial agglomeration can provide a broad variety of intermediate input with a relatively low price. Thus, degree of industrial agglomeration can measure the availability and price of intermediate input in a given industry.

From what mentioned above, we can conclude influences as below: (1) characteristics of firm; (2) market capacity; (2) factor cost: labor cost and land cost; (3) degree of industrial agglomeration in a given industry; (4) geographical distance. Because firms' location decision is a discrete choice issue, we have used conditional logistic model (CLM) which allows discrete dependent variable. We have assumed enterprises select a region according to the principle of expected profit maximization, construct a CLM to estimate influences on probability of firm choose a region, see Eq. 2.

$$
\mathrm{Y}_{\mathrm{ir}}=\beta_{\mathrm{i}} \mathrm{X}_{\mathrm{i}}+\varepsilon_{\mathrm{i}}
$$

where $Y_{\text {ir }}$ can be assigned 0 or 1 , and the probabilistic cumulative distribution function of $Y_{\text {ir }}: P\left(Y_{\text {ir }}\right)$ can be calculated as Eq. 3 .

$$
\ln \left(\mathrm{P}_{\mathrm{i}} / 1-\mathrm{P}_{\mathrm{i}}\right)=\alpha+\beta_{\mathrm{i}} \mathrm{X}_{\mathrm{i}}+\varepsilon_{\mathrm{i}}
$$

\section{Sample and Methodology}

Sample. In order to target cross-regional enterprises, 1001 manufacturing public companies and 2405 subsidiaries were used as samples. We collected and sorted samples from annual reports in 2014 according to certain principles: companies have been in operation for more than 3 years without material assets reorganization. Public companies are usually considered as having market power and technological advantage. Therefore, their location choice behavior can represent the trend of Chinese enterprises to some extent. Within these public companies, $72.3 \%$ enterprises have adopted cross-regional location strategy and nearly half of them have transferred or built R\&D units away from their parent companies. We employed Hirshman-Herfindahl index (HHI) to show detailed descriptive statistics relating to the enterprises' location characteristics which are shown in Table1. All HHI results calculated were needed to multiply a factor of 10000 for easier comparison.

Table 1 Geographical distribution of Chinese manufacturing public enterprises (HHI)

\begin{tabular}{c|c|c|c|c}
\hline Area & $\begin{array}{c}\text { Public companies } \\
\text { HHI } \times 10000\end{array}$ & $\begin{array}{c}\text { Public companies } \\
\text { cross-regional }) \\
\text { HHI } \times 10000\end{array}$ & $\begin{array}{c}\text { Production units } \\
\text { HHI } \times 10000\end{array}$ & $\begin{array}{c}\text { R\&D units } \\
\text { HHI } \times 10000\end{array}$ \\
\hline Eastern region & 675.921 & 727.41 & 352.520 & 591.151 \\
Central region & 56.527 & 52.72 & 122.083 & 63.793 \\
Western region & 22.665 & 19.74 & 60.202 & 30.510 \\
\hline
\end{tabular}

Source: Public companies' annual reports in 2014 from http://www.cninfo.com.cn/ 
Table 1 outlines degree of firm concentration. Most Chinese manufacturing public firms remained concentrated in the eastern area. As for difference between production and R\&D units, imbalance of spatial distribution was more apparent with R\&D units than production units.

Procedure and variables. There were two parts of our analysis. First, firm heterogeneity and other influences on cross-regional choice decision were tested(Model-1 and Model-2). Second, we explored the factors on the location choice of different process units(Model-3). Both two parts were tested using conditional logistic regression. With dependent variable, we began by analyzing firm heterogeneity and other determinants of the cross-regional decision according to conventional specification used in conditional logistic regression where $Y_{\text {ir }}$ in Eq. 2 is 1 when firm chooses city $r$ to locate its subsidiary and 0 for other alternative cities(Model-1 and Model-2). Secondly, to identify differences of location choice between production and R\&D units, we set $Y_{\text {ir }}$ in Eq. 2 is 1 when firm chooses city $r$ to locate its R\&D subsidiary and 0 for production subsidiary(Model-3).

For independent variables, we used the number of employees $\left(\mathrm{X}_{1}\right)$, the percentage of workers educated to degree level $\left(\mathrm{X}_{2}\right)$ and research spending $\left(\mathrm{X}_{3}\right)$ as measurements of firm characteristics. City's GDP per person $\left(\mathrm{X}_{4}\right)$, average wage of employees $\left(\mathrm{X}_{5}\right)$ and land prices $\left(\mathrm{X}_{6}\right)$ were adopted to respectively measure market capacity, cost of labor and land element. As literature, price of intermediate products can be reduced by industrial agglomeration. Thus we introduced agglomeration degrees of the given industry $\left(\mathrm{X}_{7}\right)$. Geographical distance $\left(\mathrm{X}_{8}\right)$ between parent company and its subsidiary can be measured by length of highways. Finally a dummy variable $\left(\mathrm{X}_{9}\right)$ was used to show if the target firm locate itself or its R\&D units in the eastern area. All the data was collected from firms' annual reports, Chinese City Statistical Yearbook(2014) and Chinese Land Resource Statistical Yearbook(2014).

\section{Results}

Heterogeneity and cross-regional location determinants. The results were shown in Table 3. In column 1, the results illustrated the characteristics of firms that adopted cross-regional strategy(see Model-1). Results of the analysis partly support previous hypotheses. Firm scale and the proportion of educated employees had significant effect on cross-regional decision. However, the effect of research spending on cross-regional decision was not supported by the data. It was likely that enterprises perceived the knowledge spillover risk of high input on research and development during spatial dispersion. For location factors(see Model-2), market capacity had significantly negative effect on cross-regional decision. Both labor cost and land cost were positively related to cross-regional decision. We can draw conclusion that firms are inclined to break the "tyranny of geography" of the host city with smaller market capacity and higher factor cost.

Table 3 Results of the determinants of cross-regional development

\begin{tabular}{cccc}
\hline \multirow{2}{*}{ variables/model } & \multicolumn{3}{c}{ Enterprises cross-regional decision } \\
\cline { 2 - 4 } & Model-1 & Model-2 & Model-3 \\
\hline $\mathrm{X}_{1}$ & $0.5076^{* * *}(7.1110)$ & $2.3364^{* * *}(5.0108)$ & \\
$\mathrm{X}_{2}$ & $0.8032^{* *}(1.7757)$ & $1.8771^{* * *}(4.2592)$ & \\
$\mathrm{X}_{3}$ & $0.0215(0.2228)$ & & \\
$\mathrm{X}_{4}$ & & $-1.0035^{* * *}(-2.6760)$ & $0.9248^{* *}(2.0582)$ \\
$\mathrm{X}_{5}$ & $0.8013^{* *}(0.9185)$ & $1.0212^{* * *}(2.5093)$ \\
$\mathrm{X}_{6}$ & $0.9030^{* * *}(2.1290)$ & $0.9294 * *(1.6215)$ \\
$\mathrm{X}_{7}$ & & $1.3549 * *(1.9819)$ \\
$\mathrm{X}_{8}$ & & & $-2.0017 * * *(-2.9291)$ \\
$\mathrm{X}_{9}$ & & 1001 & $0.4218^{* * *(3.7711)}$ \\
$\mathrm{N}$ & 1001 & 0.5979 & 2405 \\
McFadden $\mathrm{R}^{2}$ & 0.4854 & -623.2012 & 0.3325 \\
Log likelihood & -601.5528 & & -1432.361 \\
\hline Note: *Significant at $0.01,{ }^{* *}$ Significant at $0.05, * * *$ Significant at 0.1 &
\end{tabular}

Location choice of different subsidiaries. In Model-3, we introduced a dummy variable to investigate location preference. The results revealed that all location factors turned out to be positive 
and significant $(\mathrm{p}<0.5)$. Different from production units, location choices of $R \& D$ units are inclined to be located in cites with bigger market capacity and higher factor costs. Combining the result of dummy variable, it is clear that most Chinese public enterprises located their $R \& D$ units in the eastern area through higher labor and land cost in these regions. Another interesting conclusion was that geographical distance negatively affected $R \& D$ units' location choice $(p<0.01)$. R\&D units have higher location lock-in effect than production units which have been more likely to be transferred to remote area. This lock-in effect around parent company and developed regions also can be explained as an outcome of knowledge and physical activities' strong dependency upon the availability of skilled worker.

\section{Conclusions}

This study explored the characteristics and determinants of cross-regional strategies of Chinese manufacturing enterprises by extending expected profit function with firm heterogeneity. Our work generated following research conclusions:

(1) larger enterprises with higher technical level are more likely to implement cross-regional strategy to achieve superior geographical conditions, for example lower factor cost and bigger market;

(2) however, location choices of R\&D units are still locked in the in cites with higher factor costs, greater market size and thriving industrial agglomeration to acquire high skilled professionals and information.

The empirical findings presented in this study also provide helpful suggestion to firms may consider implementing cross-regional strategy.Production dispersing and $\mathrm{R} \& \mathrm{D}$ concentrating may be a feasible way to pursuit both lower cost and senior resources. For local government, it may be necessary to introduce superior enterprises and take advantage of their cross-regional development mode to promote cooperation between two cities.

\section{Acknowledgements}

This work was financially supported by the National Natural Science Foundation (71173182).

\section{References}

[1] R. Kneller, D. McGowan, T. Inui and T. Matsuura: Closure within multi-plant firms: evidence from Japan. Review of World Economics. Vol.148 (2012), p. 647-668.

[2] R. E. Baldwin and T. Okubo: Heterogeneous firms, agglomeration and economic geography: spatial selection and sorting. Journal of Economic Geography. Vol.6 (2006), p.323- 346.

[3] S. Mariotti, P. Lucia P and E. Stefano: Spatial agglomeration of multinational enterprises: the role of information externalities and knowledge spillovers. Journal of Economic Geography. Vol. 4 (2010), p.519-538.

[4] A. Bernard, S. Redding and P. Schott: Comparative advantage and heterogeneous firms. Review of Economic Studies, Vol.74 (2007), p.31-66.

[5] M. Melitz M and G. I. P. Ottaviano: Market size, trade, and productivity. Review of Economic Studies, Vol. 75(2008), p. 295 - 316.

[6] M. Amiti and B. Javorcik: Trade Costs and Location of Foreign Firms in China. Journal of Development Economics. Vol. 85 (2008), p. 129-149.

[7] G. I. P. Ottaviano: "New"new economic geography: firm heterogeneity and agglomeration economies. Journal of Economic Geography. Vol.11 (2011), p. 231-240.

[8] T. Inui, T. Matsuura and S. Poncet: The Location of Japanese MNC Affiliates:Agglomeration, Spillovers and Firm Heterogeneity. CEPII Discussing Paper. (2008). 